\title{
Factors influencing the entrepreneurial engagement of opportunity and necessity entrepreneurs
}

\author{
Peter van der Zwan ${ }^{1} \cdot$ Roy Thurik $^{1,3}$ (D) \\ Ingrid Verheul $^{2} \cdot$ Jolanda Hessels ${ }^{1}$
}

Received: 29 July 2016/Revised: 11 October 2016/ Accepted: 17 October 2016/

Published online: 3 November 2016

(C) The Author(s) 2016. This article is published with open access at Springerlink.com

\begin{abstract}
The scholarly literature often distinguishes between so-called opportunity and necessity entrepreneurship and between "pull" and "push" motivations. Despite the pervasive use of this terminology, empirical analyses are mostly based on a single country. The present paper contributes by investigating business owner survey data for the United States and 32 countries in Europe and Asia. We analyze the differences between business owners motivated by opportunity and necessity in terms of their (1) socioeconomic characteristics, (2) personality, and (3) perceptions of entrepreneurial support. Descriptive statistics reveal that the two groups of business owners have very different profiles along these three dimensions. Moreover, multinomial logit regressions indicate that the determinants of business ownership (versus paid employment) differ for opportunity and necessity business ownership. A specific result of the present study (covering all 33 countries) is that the probability of being an opportunity versus a necessity business owner is higher for male, younger, wealthier, proactive, and optimistic business owners. Furthermore, those who prefer being a business owner and those who have more favorable perceptions of financial start-up support are more likely to be an opportunity versus a necessity business owner.
\end{abstract}

\footnotetext{
The original version of this article was revised: Due to a technical mistake in Table 3 the asterisks were placed after the second value (standard errors) instead of after the first value (coefficient). In addition there should have been parentheses around the second values (standard errors) in lines. The publisher apologizes for this mistake.

$\triangle$ Peter van der Zwan

vanderzwan@ese.eur.nl

1 Erasmus School of Economics, Erasmus University Rotterdam, P.O. Box 1738, 3000 DR Rotterdam, The Netherlands

2 Rotterdam School of Management, Erasmus University Rotterdam, P.O. Box 1738, 3000 DR Rotterdam, The Netherlands

3 Montpellier Business School, 2300 Avenue des Moulins, 34185 Montpellier Cedex 4, France
} 
Keywords Entrepreneurship - Opportunity · Necessity · Motivation · Personality · Perceptions

JEL Classification J24 $\cdot$ M13 $\cdot$ L26

\section{Introduction}

Why does an individual take the personal and financial risks associated with setting up a new venture? Individuals decide to engage in entrepreneurial activity because of different (combinations of) start-up motivations. Generally, a distinction is made between positive factors that 'pull' and negative factors that 'push' people into entrepreneurship (Shapero and Sokol 1982; Gilad and Levine 1986). Examples of 'pull' motivations include the need for achievement, the desire to be independent, and opportunities for social development. 'Push' motivations may arise from (the risk of) unemployment, family pressure, and individuals' general dissatisfaction with their current situation. In the present paper, we distinguish between two groups of individuals depending on their pull or push motivations for entrepreneurship. First, by means of a univariate analysis, we compare the two groups on the basis of commonly investigated individual-level characteristics that determine entrepreneurial engagement (see Simoes et al. 2015, for an overview of these characteristics). Second, using multinomial logit regressions, we investigate whether these characteristics drive entrepreneurial engagement differently for the two groups.

In the Global Entrepreneurship Monitor, Reynolds et al. (2001) capture the distinction between pull and push motivations by introducing the concept of opportunity and necessity entrepreneurship. Although various measures of opportunity and necessity entrepreneurship exist, it is generally agreed upon that pull factors form the basis for opportunity entrepreneurs to set up a new venture, while necessity entrepreneurs are driven mainly by push motivations. Opportunity entrepreneurship reflects start-up efforts "to take advantage of a business opportunity", whereas necessity entrepreneurship exists when there are "no better choices for work" (Reynolds et al. 2005, p. 217). Although opportunity entrepreneurs pursue a business opportunity for personal interest (often when they are still wage employed), entrepreneurship is often the best "but not necessarily the preferred option" for individuals who start out of necessity (Reynolds et al. 2001, p. 8).

The start-up motivation has consequences for the way in which a business is managed, for example, in terms of business aspirations (Hessels et al. 2008), the market entry strategy (Block et al. 2015a), and business performance. Specifically, necessity entrepreneurs are characterized by lower satisfaction levels (Block and Wagner 2010; Galbraith and Latham 1996; Block and Koellinger 2009; Kautonen and Palmroos 2010), lower returns to education (Fossen and Büttner 2013), inferior performance (Vivarelli 2013), and shorter spells in entrepreneurship (Block and Wagner 2010; Amit and Muller 1995; Vivarelli 2004) than opportunity entrepreneurs. Furthermore, a positive relationship between health status and 
opportunity entrepreneurship has been found, while such a relationship is absent for necessity entrepreneurship (Rietveld et al. 2016). At the macro level, opportunity and necessity entrepreneurs appear to have a differential impact on economic growth, job creation, and aspirations (Acs 2006; Wennekers et al. 2005; Wong et al. 2005; Hessels et al. 2008). Finally, in their study on the interplay between the business cycle and the entrepreneurship cycle Koellinger and Thurik (2012) show that opportunity entrepreneurship leads the cycle by two years, while necessity entrepreneurship leads the cycle by only one year (see also Thurik 2014). While their explanation based upon 'legitimation' or 'moral approval' is somewhat speculative, there may be important policy implications given that start-up motives seem to interact differently with the cycle.

Earlier research has hinted at differences between opportunity and necessity entrepreneurs in terms of their socioeconomic characteristics, such as their level of education, relevant experience and age (Amit and Muller 1995; Block and Wagner 2010; Fossen and Büttner 2013). Moreover, the determinants of opportunity and necessity entrepreneurship may differ (Morales-Gualdrón and Roig 2005; XavierOliveira et al. 2015). This has important implications for policy making because measures to stimulate necessity entrepreneurship do not necessarily benefit opportunity-driven entrepreneurs, and vice versa. For example, encouraging the unemployed to start a business will benefit necessity and not opportunity entrepreneurs (Bergmann and Sternberg 2007). In general, fragmented evidence has been generated in terms of potentially different characteristics and drivers of opportunity and necessity entrepreneurship. The present paper contributes to the current literature in two ways. First, we attempt to find robust evidence of distinctive characteristics and drivers of opportunity and necessity entrepreneurs(hip) by drawing upon an international database covering more than 30 countries. While existing studies investigate opportunity and necessity motivations only at the national level, our approach allows us to control for cross-country heterogeneity. Second, we extend the set of characteristics by taking into account not only an individual's socioeconomic profile but also an individual's personality and perceptions of entrepreneurial support. Personality and perceptions have not received much attention in this research domain. Personality is an important dimension because it influences the preference to become self-employed (Verheul et al. 2012) and self-employment entry and exit decisions (Caliendo et al. 2014). Perceptions of the entrepreneurial climate are also important factors at various stages of the entrepreneurial process (Grilo and Thurik 2008; Van der Zwan et al. 2010). Linkages between start-up motivation and personality may explain why opportunity entrepreneurs perform better than necessity entrepreneurs.

In the present study, we examine the differences between opportunity and necessity business owners in terms of their (1) socioeconomic characteristics, (2) personality, and (3) perceptions of barriers to entrepreneurship. A univariate analysis answers the questions of whether opportunity and necessity business owners have different profiles and which characteristics are more prevalent among these groups of business owners. Furthermore, we assess the extent to which the characteristics under study have a differential impact on opportunity and necessity business ownership. This analysis, based on multinomial logit regressions, allows an assessment of the factors that differently hinder or stimulate opportunity and 
necessity business ownership versus paid employment. We use 2009 survey data from the Flash Eurobarometer survey on entrepreneurship, consisting of almost 2000 business owners and approximately 7000 paid employees in Europe, Asia, and the United States. We use self-reports by individuals who indicated whether they started a business because of an opportunity or out of necessity. It is not uncommon to use self-reports in empirical work to capture the distinction between opportunity and necessity entrepreneurship (Tables 2-4 in Bosma 2013).

The remainder of the paper is structured as follows. In the next section, the concepts of opportunity and necessity entrepreneurship are discussed and compared to pull and push motivations. This section also elaborates on earlier findings on the differences between opportunity and necessity entrepreneurs. In Sect. 3, we introduce the data and methodology. The results of our analyses are shown in Sect. 4 , and the paper ends with the conclusion.

\section{Literature background}

\subsection{Pull versus push motivation}

Different scholars have contributed to our understanding of the supply of entrepreneurship (Hamilton and Harper 1994). Apart from the (perceived) ability to become an entrepreneur, determined by factors such as human, social and financial capital, individuals have to show a willingness to become self-employed. Indeed, Ajzen's (1991) theory of planned behavior distinguishes between an attitude towards the intended behavior (i.e., self-employment) and (perceived) behavioral control (i.e., whether people believe they have it in them to become selfemployed). As an important driver of intended entrepreneurial behavior, attitudes essentially capture the motivation to engage in entrepreneurial behavior. Gilad and Levine (1986) distinguish between pull and push "hypotheses" of entrepreneurial motivation. The distinction between pull and push factors is also implicitly present in the Model of the Entrepreneurial Event (Shapero and Sokol 1982), where it is argued that the act of starting up a business is dependent upon a displacement (or important change) occurring in the life of an individual. This displacement can be negative, in the form of the loss of a job or a divorce, but it may also be positive, such as an inheritance. ${ }^{1}$ Individual characteristics (including sociocultural factors and economic, social and human capital) determine how individuals experience, value and perceive 'disruptive' events (Shapero and Sokol 1982) or encountered opportunities as well as how they react to them. It is not only an individual's objective situation but also his/her perception that makes him/her decide on an entrepreneurial career. In reaction to a certain 'disruptive' event, some may start a business, whereas others go in a different direction.

Pull motivations come in different forms. Shane et al. (1991) find evidence for four motivational constructs: recognition, independence, learning and roles (the last of

\footnotetext{
${ }^{1}$ Based on the desirability and feasibility of starting a business, this displacement will eventually determine whether an individual actually engages in entrepreneurial activity.
} 
which are driven by the wish to continue the family tradition, to have more influence in the community, and to follow a role model). Carter et al. (2003) distinguish between six categories of motivation: innovation, independence, recognition, roles, financial success and self-realization. Innovative firms are central to economic development and the evolution of industries, and entrepreneurs differ in their likelihood to engage in process and/or product innovation (Agarwal and Shah 2014). Indeed, many firm-level sources determine innovative behavior (Pellegrino et al. 2012). We know that necessity entrepreneurs are less likely to be involved in product innovation than opportunity entrepreneurs (Darnihamedani and Hessels 2016). Furthermore, larger firms are more likely to pursue Schumpeterian opportunities-focused on discontinuous change - while small ventures are more likely to pursue Kirznerian opportunities that are less focused on innovation (De Jong and Marsili 2015). ${ }^{2}$

Finally, there are categorizations of pull motivations in studies by Birley and Westhead (1994) and Scheinberg and MacMillan (1988), each providing evidence of a multitude of pull motivations, including the need for approval, independence, personal development, improved welfare and wealth, and following role models.

In terms of push motivations, Oxenfeldt (1943) was one of the first to argue that unemployed individuals or individuals with low prospects for wage employment may become self-employed to earn a living. This can be traced back to Knight's (1921) view that individuals choose between three activities: unemployment, self-employment and wage employment. The effect of unemployment-i.e., lowering the opportunity costs of self-employment, thereby driving individuals to start their own business - is often referred to as the push effect of unemployment. Evidence of this unemployment push or "escape from unemployment" effect has been provided in several studies (Storey and Jones 1987; Audretsch and Vivarelli 1996; Foti and Vivarelli 1994; Ritsilä and Tervo 2002; Gilad and Levine 1986; Thurik et al. 2008; Vivarelli 2013; Rocha et al. 2015). In studies explaining the decision to become selfemployed, push motivation is usually connected to unemployment; however, there are other factors that may push individuals into the direction of new venture creation, such as family pressure to transfer the business to the new generation (Giacomin et al. 2011) or job dissatisfaction (Hisrich and Brush 1986; Brockhaus 1980; Cromie and Hayes 1991). Sarasvathy (2004) proposes different types of necessity entrepreneurs, including individuals who are fired from their jobs; individuals who decide to leave wage employment because their boss does not want to commercialize their ideas or inventions; and individuals who are "unhireable", for example, due to a lack of educational or language skills (immigrant entrepreneurs) or criminal backgrounds.

Notwithstanding the role played by the different motives mentioned above, the wish to be independent is generally agreed upon as the dominant factor explaining new venture creation (Scheinberg and MacMillan 1988; Birley and Westhead 1994). Entrepreneurs are characterized by higher levels of work satisfaction than individuals in paid employment (Benz and Frey 2008a), which has been attributed to the high degree of autonomy experienced in entrepreneurship (Benz and Frey 2008b). One could thus conclude that individuals are more likely to be pulled than pushed into entrepreneurship.

\footnotetext{
${ }^{2}$ In addition, the innovation behavior-which could be related to export performance: Gkypali et al. (2015) — of small firms is less persistent than that of large firms (García-Quevedo et al. 2014).
} 
However, this does not mean that other factors than autonomy or independence do not play a role in this occupational decision. For example, in a large study investigating start-up motivations (Stephan et al. 2015), the pursuit of earning additional income is mentioned frequently. Individuals may also be driven by a combination of factors. As recognized by Birley and Westhead (1994), p. 14: “...starting a business is a complex process which involves a variety of motivations and stimuli". Hence, next to the "pure' pull- and push-motivated individuals, there may be (potential) entrepreneurs who are motivated by a combination of such factors. Several studies highlight the possibility that pull and push factors are simultaneously present when an individual decides to start a business (Giacomin et al. 2011; Block and Sandner 2009).

\subsection{Earlier evidence}

Research on the link between individual characteristics and entrepreneurial motivation has yielded contradictory findings, caused in part by the different definitions of opportunity and necessity entrepreneurship and the variety of samples under investigation.

Our empirical analysis first focuses on the potentially different profile of opportunity and necessity business owners on the basis of the following dimensions: (1) socioeconomic characteristics, (2) personality, and (3) perceptions of barriers to entrepreneurship.

Regarding socioeconomic differences between opportunity and necessity entrepreneurs, the following patterns have emerged from previous research. The relationship between gender and start-up motivation appears to be weak while different age patterns have been observed for opportunity and necessity entrepreneurs (Stephan et al. 2015). Specifically, opportunity entrepreneurs are generally older than necessity entrepreneurs (Block and Sandner 2009; Fossen and Büttner 2013). Research has shown that the education level of opportunity entrepreneurs is higher than that of necessity entrepreneurs (Fossen and Büttner 2013; Stephan et al. 2015), although a difference in education level is not observed by Block and Wagner (2010). Furthermore, according to Amit and Muller (1995), a higher percentage of "push entrepreneurs" report a neutral attitude towards entrepreneurship from their parents, whereas "pull entrepreneurs" are more likely to be either encouraged or discouraged to engage in entrepreneurial activity by their parents. Finally, household income seems to be higher among opportunity than among necessity entrepreneurs (Stephan et al. 2015).

In terms of personality, research has shown that opportunity and necessity entrepreneurs have similar risk attitudes (Amit and Muller 1995; Tyszka et al. 2011; Fossen and Büttner 2013). Other personality characteristics have rarely been considered, although scarce evidence shows that opportunity entrepreneurs have lower levels of neuroticism and an external locus of control (Fossen and Büttner 2013) and higher levels of general self-efficacy (Tyszka et al. 2011) than necessity entrepreneurs. ${ }^{3}$ Studies have not yet compared opportunity and necessity entrepreneurs with respect to their perceptions of the entrepreneurial support infrastructure.

\footnotetext{
${ }^{3}$ Note that these studies use European samples. A study performed in Mexico (Calderon et al. 2016) yields that opportunity entrepreneurs are younger than their necessity counterparts. It finds evidence contrary to the studies above in terms of personality but focuses only on female entrepreneurs.
} 
The second step of our analysis is to focus on whether the characteristics that determine the probability of being a business owner versus a paid employee are different for opportunity and necessity business owners. Generally, research focusing on such distinctive determinants of opportunity and necessity entrepreneurship is scarce. There have been some indications of possible differences (Morales-Gualdrón and Roig 2005). For example, Bergmann and Sternberg (2007) do not find a significant effect of age on necessity nascent entrepreneurship, while age has an inverse U-shaped relationship with opportunity nascent activity. Education level and household income are positively related to opportunity entrepreneurship but negatively to necessity entrepreneurship in Xavier-Oliveira et al. (2015). A thorough investigation including personality factors and perceptions has not been performed in earlier research. ${ }^{4}$

\section{Data and methodology}

To test for differences between opportunity and necessity entrepreneurs, we use individual-level data from the 2009 Flash Eurobarometer survey on entrepreneurship (No. 283) carried out on behalf of the European Commission. In December 2009, randomized interviews were conducted by the Gallup Organization Europe with respondents aged 15 years and over. Information was collected for the then 25 Member States of the European Union, four other European countries (Iceland, Norway, Switzerland, Turkey), three Asian countries (China, Japan, South Korea), and the United States. ${ }^{5}$

\subsection{Opportunity and necessity business ownership}

Individuals who indicated that they had started a business either in the past three years or in the period prior to that were identified as business owners. These business owners indicated whether they had started a business because they "came across an opportunity" or "because it was a necessity". Although there are studies using other categorizations, such as Block and Wagner (2010) and Tyszka et al. (2011), a self-assessment is also used in the context of the Global Entrepreneurship Monitor (Reynolds et al. 2005). The number of business owners associated with each motivation in our sample amounted to 1004 (60\%) opportunity-motivated and $672(40 \%)$ necessity-motivated business owners, for a total of 1676 business owners whose entrepreneurial motivation was known. In addition, our sample consisted of 7048 individuals in paid employment. When unraveling the determinants of business ownership, we compared the opportunity and necessity business owners

\footnotetext{
${ }^{4}$ An exception is the Vietnamese sample investigated by Brünjes and Diez (2013), where risk-taking propensity is positively and significantly related to opportunity entrepreneurship but unrelated to necessity entrepreneurship.

5 Bulgaria and Rumania were not included since they were not yet Member States of the European Union in 2007. More information about the coverage and fieldwork of Flash Eurobarometer surveys is provided here: http://www.gesis.org/eurobarometer-data-service/survey-series/flash-eb (accessed: August 12, 2016).
} 
with the group of paid employees. Discriminating between entrepreneurship (in the present case, business ownership) and paid employment is consistent with the extant literature on the determinants of entrepreneurship (Simoes et al. 2015).

\subsection{Other variables}

Following the overview of individual-level determinants of entrepreneurial engagement in Simoes et al. (2015), we focus on the following socioeconomic characteristics: gender, age, education, family background in terms of selfemployed parents, and financial resources measured by household income. In addition, we include an individual's preference for self-employment versus paid employment_latent entrepreneurship (Blanchflower et al. 2001) - because this may represent an important difference between opportunity and necessity business owners. We also take into account an individual's personality. We focus on an individual's risk attitude (Parker 1996, 1997) and other relevant personality characteristics, including general self-efficacy, locus of control, proactiveness, autonomy, innovativeness, optimism, and competitiveness (see Bönte and Piegeler 2013). Finally, we add perceived environmental barriers to entrepreneurship, as these have been reported as important factors when explaining entrepreneurial activity (Arenius and Minniti 2005; Koellinger and Minniti 2006; Grilo and Thurik 2008; Van der Zwan et al. 2010). Larger values for the perception variables indicate more negative perceptions about the environment. Country dummies are included in all our regressions to control for country-specific influences. ${ }^{6}$

Table 1 provides an overview of the variables. A correlation matrix is shown in Table 4 (Appendix).

\section{Results}

\subsection{Profile of opportunity and necessity business owners}

Table 2 displays the variable averages for paid employees, opportunity business owners, and necessity business owners. Regular two-sided $t$-tests are carried out to investigate the significance of the differences across the three groups for each variable.

The last column of Table 2 shows the difference between opportunity and necessity business owners. For socioeconomic characteristics, we note that opportunity business owners are significantly more likely to be male, younger, and wealthier in terms of household income and to have a higher preference for business ownership versus paid employment than necessity business owners. Interestingly, opportunity and necessity business owners have similar education levels and do not significantly differ in terms of the self-employment background of their parents.

\footnotetext{
${ }^{6}$ Experience (managerial, industry, self-employment), health situation, the presence of a self-employed spouse, marital status, and number of children are included in the overview of the individual-level determinants of entrepreneurship of Simoes et al. (2015) but are not included in our questionnaire.
} 
Table 1 Individual explanatory variables

\begin{tabular}{|c|c|}
\hline Variable name & Variable description/questionnaire item \\
\hline \multicolumn{2}{|l|}{ Socioeconomic factors } \\
\hline Male & Male $(=1)$ or female $(=0)$ \\
\hline Age & Age of the respondent in years $(15-89)$ \\
\hline Education & Age when finished full-time education (15-25) \\
\hline Self-employed parents & At least one parent self-employed (1); none self-employed (0) \\
\hline Household income & $\begin{array}{l}\text { Perceived household income }(1=\text { very hard to manage on the present } \\
\text { income; } 2=\text { difficult; } 3=\text { get by; } 4=\text { live comfortably })\end{array}$ \\
\hline $\begin{array}{l}\text { Preference for self- } \\
\text { employment }\end{array}$ & Preference for being self-employed (1) versus being an employee (0) \\
\hline \multicolumn{2}{|l|}{ Personality } \\
\hline Risk-taking propensity & $\begin{array}{l}\text { In general, I am willing to take risks }(1=\text { strongly disagree; } \\
2=\text { disagree; } 3=\text { agree; } 4=\text { strongly agree })\end{array}$ \\
\hline General self-efficacy & $\begin{array}{l}\text { Generally, when facing difficult tasks, I am certain that I will accomplish } \\
\text { them (1-4) }\end{array}$ \\
\hline Internal locus of control & $\begin{array}{l}\text { My life is determined by my own actions, not by others or by chance } \\
(1-4)\end{array}$ \\
\hline Proactiveness & If I see something I do not like, I change it (1-4) \\
\hline Autonomy & $\begin{array}{l}\text { The possibility of being rejected by others for standing up for my } \\
\text { decisions would not stop me (1-4) }\end{array}$ \\
\hline Innovativeness & I am an inventive person who has ideas (1-4) \\
\hline Optimism & I am optimistic about my future (1-4) \\
\hline Competitiveness & I like situations in which I compete with others (1-4) \\
\hline \multicolumn{2}{|l|}{ Environmental perceptions } \\
\hline $\begin{array}{l}\text { Perception lack of } \\
\text { financial support }\end{array}$ & $\begin{array}{l}\text { It is difficult to start one's own business due to a lack of available } \\
\text { financial support }(1=\text { strongly disagree; } 2=\text { disagree; } 3=\text { agree; } \\
4=\text { strongly agree })\end{array}$ \\
\hline $\begin{array}{l}\text { Perception administrative } \\
\text { complexities }\end{array}$ & $\begin{array}{l}\text { It is difficult to start one's own business due to the complex administrative } \\
\text { procedures (1-4) }\end{array}$ \\
\hline $\begin{array}{l}\text { Perception insufficient } \\
\text { information }\end{array}$ & $\begin{array}{l}\text { It is difficult to obtain sufficient information on how to start a business } \\
(1-4)\end{array}$ \\
\hline
\end{tabular}

Regarding the personality factors, we observe that all factors are more prevalent among opportunity business owners than among necessity business owners. Finally, necessity business owners are significantly more negative about the availability of financial support and start-up information than opportunity business owners. Perceptions of administrative complexities are not significantly different between the two groups of business owners.

\subsection{Motivation and engagement}

This section examines the impact of our individual-level characteristics on the probability of being an opportunity business owner versus a paid employee and on the probability of being a necessity business owner versus a paid employee. A multinomial logit model is used with three categories: paid employment, 
Table 2 Averages of variables for paid employees, opportunity business owners, and necessity business owners

$\begin{array}{llllll}\begin{array}{l}\text { Paid } \\ \text { employment }\end{array} & \begin{array}{l}\text { Opportunity } \\ \text { business }\end{array} & \begin{array}{l}\text { Necessity } \\ \text { business } \\ \text { ownership }\end{array} & \begin{array}{l}\text { Difference } \\ (1)-(2)\end{array} & \begin{array}{l}\text { Difference } \\ (1)-(3)\end{array} & \begin{array}{l}\text { Difference } \\ (2)-(3)\end{array} \\ & (2) & (3) & & & \\ \end{array}$

\begin{tabular}{|c|c|c|c|c|c|c|}
\hline \multicolumn{7}{|l|}{ Socioeconomics } \\
\hline Male & 0.44 & 0.63 & 0.55 & $-0.19^{* * *}$ & $-0.11 * * *$ & $0.08 * * *$ \\
\hline Age & 43.63 & 48.08 & 49.95 & $-4.45^{* * *}$ & $-6.32 * * *$ & $-1.87 * * *$ \\
\hline Education & 20.13 & 20.40 & 20.15 & $-0.28 * * *$ & -0.02 & 0.25 \\
\hline Self-employed parents & 0.24 & 0.38 & 0.39 & $-0.15^{* * *}$ & $-0.15^{* * *}$ & -0.01 \\
\hline Household income & 2.93 & 3.14 & 2.80 & $-0.21^{* * *}$ & $0.13 * * *$ & $0.34 * * *$ \\
\hline $\begin{array}{l}\text { Preference for self- } \\
\text { employment }\end{array}$ & 0.38 & 0.81 & 0.77 & $-0.42 * * *$ & $-0.39 * * *$ & $0.04 *$ \\
\hline \multicolumn{7}{|l|}{ Personality } \\
\hline Risk-taking propensity & 2.72 & 2.99 & 2.85 & $-0.27 * * *$ & $-0.13 * * *$ & $0.14 * * *$ \\
\hline General self-efficacy & 3.10 & 3.22 & 3.13 & $-0.12 * * *$ & -0.03 & $0.10 * * *$ \\
\hline Internal locus control & 3.15 & 3.29 & 3.21 & $-0.14 * * *$ & $-0.05 * *$ & $0.09 * * *$ \\
\hline Proactiveness & 3.05 & 3.21 & 3.08 & $-0.16^{* * *}$ & -0.03 & $0.13 * * *$ \\
\hline Autonomy & 3.04 & 3.21 & 3.09 & $-0.17 * * *$ & $-0.05^{*}$ & $0.12 * * *$ \\
\hline Innovativeness & 3.03 & 3.24 & 3.13 & $-0.21 * * *$ & $-0.10 * * *$ & $0.11 * * *$ \\
\hline Optimism & 3.03 & 3.20 & 3.01 & $-0.18^{* * *}$ & 0.01 & $0.19 * * *$ \\
\hline Competitiveness & 2.61 & 2.83 & 2.66 & $-0.22 * * *$ & -0.04 & $0.18 * * *$ \\
\hline \multicolumn{7}{|l|}{ Perceptions } \\
\hline $\begin{array}{l}\text { Lack of financial } \\
\text { support }\end{array}$ & 3.16 & 3.02 & 3.16 & $0.13^{* * *}$ & 0.00 & $-0.14 * * *$ \\
\hline $\begin{array}{r}\text { Administrative } \\
\text { complexities }\end{array}$ & 2.97 & 2.81 & 2.86 & $0.16^{* * *}$ & $0.12 * * *$ & -0.04 \\
\hline $\begin{array}{l}\text { Insufficient } \\
\text { information }\end{array}$ & 2.62 & 2.46 & 2.65 & $0.16^{* * *}$ & -0.03 & $-0.19 * * *$ \\
\hline
\end{tabular}

* Denotes significantly different from zero at $10 \%$; ** at 5\%; *** at $1 \%$. Two-sided $t$-tests have been performed. Table based on the full sample of 8724 observations

opportunity business ownership, and necessity business ownership (8724 observations in total). Columns 1 and 2 of Table 3 take paid employment as the reference category. Hence, the coefficients in these columns have to be interpreted relative to paid employment and provide insight into the determinants of opportunity and necessity business ownership.

As a first exercise, we determine whether the coefficients in columns 1 and 2 are identical. In other words, we assess whether the two categories of opportunity and necessity business ownership are distinct. We use Wald tests to assess the joint significance of the coefficients (apart from the country dummies). We conclude that the groups of opportunity and necessity business ownership cannot be merged. ${ }^{7}$ Hence, there are different determinants of entrepreneurial engagement between the

\footnotetext{
7 The values of the test statistics are 240.32 ( $p$ value $<0.01), 27.63$ ( $p$ value $<0.01), 50.22(p$ value $<0.01$ ), and 7.63 ( $p$ value $<0.10$ ) for the full set of variables excluding the country dummies, the socioeconomic variables, the personality variables, and the perception variables.
} 
Table 3 Estimated coefficients of multinomial logit regression with paid employees, opportunity business owners, and necessity business owners

\begin{tabular}{|c|c|c|c|}
\hline & $\begin{array}{l}\text { Opportunity business } \\
\text { ownership versus } \\
\text { paid employment (1) }\end{array}$ & $\begin{array}{l}\text { Necessity business } \\
\text { ownership versus } \\
\text { paid employment (2) }\end{array}$ & $\begin{array}{l}\text { Opportunity business } \\
\text { ownership versus necessity } \\
\text { business ownership (3) }\end{array}$ \\
\hline \multicolumn{4}{|l|}{ Socio-economics } \\
\hline Male & $\begin{array}{l}0.374 * * * \\
(0.081)\end{array}$ & $\begin{array}{c}0.152 * \\
(0.078)\end{array}$ & $\begin{array}{l}0.221^{* *} \\
(0.103)\end{array}$ \\
\hline Age & $\begin{array}{l}0.039 * * * \\
(0.004)\end{array}$ & $\begin{array}{l}0.056^{* * *} \\
(0.005)\end{array}$ & $\begin{array}{c}-0.017 * * * \\
(0.006)\end{array}$ \\
\hline Education & $\begin{array}{r}-0.001 \\
(0.012)\end{array}$ & $\begin{array}{c}0.004 \\
(0.021)\end{array}$ & $\begin{array}{r}-0.005 \\
(0.018)\end{array}$ \\
\hline Self-employed parents & $\begin{array}{l}0.680 * * * \\
(0.082)\end{array}$ & $\begin{array}{l}0.569 * * * \\
(0.121)\end{array}$ & $\begin{array}{c}0.111 \\
(0.128)\end{array}$ \\
\hline Household income & $\begin{array}{l}0.289 * * * \\
(0.063)\end{array}$ & $\begin{array}{r}-0.033 \\
(0.049)\end{array}$ & $\begin{array}{l}0.323 * * * \\
(0.077)\end{array}$ \\
\hline $\begin{array}{l}\text { Preference for } \\
\text { self-employment }\end{array}$ & $\begin{array}{l}1.911 * * * \\
(0.126)\end{array}$ & $\begin{array}{l}1.589 * * * \\
(0.117)\end{array}$ & $\begin{array}{l}0.321 * * * \\
(0.124)\end{array}$ \\
\hline \multicolumn{4}{|l|}{ Personality } \\
\hline Risk-taking propensity & $\begin{array}{l}0.200^{* * *} \\
(0.041)\end{array}$ & $\begin{array}{l}0.120 * \\
(0.067)\end{array}$ & $\begin{array}{c}0.080 \\
(0.067)\end{array}$ \\
\hline General self-efficacy & $\begin{array}{r}-0.099 \\
(0.074)\end{array}$ & $\begin{array}{r}-0.103 \\
(0.105)\end{array}$ & $\begin{array}{c}0.004 \\
(0.093)\end{array}$ \\
\hline Internal locus of control & $\begin{array}{c}0.105 \\
(0.074)\end{array}$ & $\begin{array}{c}0.048 \\
(0.052)\end{array}$ & $\begin{array}{c}0.057 \\
(0.079)\end{array}$ \\
\hline Proactiveness & $\begin{array}{l}0.199 * * * \\
(0.055)\end{array}$ & $\begin{array}{c}0.043 \\
(0.069)\end{array}$ & $\begin{array}{l}0.156^{*} \\
(0.083)\end{array}$ \\
\hline Autonomy & $\begin{array}{c}0.019 \\
(0.063)\end{array}$ & $\begin{array}{r}-0.032 \\
(0.080)\end{array}$ & $\begin{array}{c}0.052 \\
(0.074)\end{array}$ \\
\hline Innovativeness & $\begin{array}{c}0.125^{*} \\
(0.068)\end{array}$ & $\begin{array}{l}0.159 * * * \\
(0.059)\end{array}$ & $\begin{array}{r}-0.034 \\
(0.084)\end{array}$ \\
\hline Optimism & $\begin{array}{c}0.136 \\
(0.096)\end{array}$ & $\begin{array}{r}-0.006 \\
(0.065)\end{array}$ & $\begin{array}{l}0.141 * \\
(0.082)\end{array}$ \\
\hline Competitiveness & $\begin{array}{c}0.030 \\
(0.041)\end{array}$ & $\begin{array}{r}-0.032 \\
(0.059)\end{array}$ & $\begin{array}{c}0.062 \\
(0.074)\end{array}$ \\
\hline \multicolumn{4}{|l|}{ Perceptions } \\
\hline $\begin{array}{l}\text { Perception lack } \\
\text { of financial support }\end{array}$ & $\begin{array}{r}-0.091 * \\
(0.053)\end{array}$ & $\begin{array}{c}0.061 \\
(0.071)\end{array}$ & $\begin{array}{r}-0.152 * \\
(0.080)\end{array}$ \\
\hline $\begin{array}{l}\text { Perception administrative } \\
\text { complexities }\end{array}$ & $\begin{array}{c}-0.105^{* *} \\
(0.050)\end{array}$ & $\begin{array}{r}-0.113 \\
(0.078)\end{array}$ & $\begin{array}{c}0.008 \\
(0.077)\end{array}$ \\
\hline $\begin{array}{l}\text { Perception insufficient } \\
\text { information }\end{array}$ & $\begin{array}{r}-0.102 * \\
(0.057)\end{array}$ & $\begin{array}{r}-0.035 \\
(0.057)\end{array}$ & $\begin{array}{r}-0.067 \\
(0.056)\end{array}$ \\
\hline
\end{tabular}


Table 3 continued

\begin{tabular}{lclc}
\hline & $\begin{array}{l}\text { Opportunity business } \\
\text { ownership versus } \\
\text { paid employment (1) }\end{array}$ & $\begin{array}{l}\text { Necessity business } \\
\text { ownership versus } \\
\text { paid employment (2) }\end{array}$ & $\begin{array}{l}\text { Opportunity business } \\
\text { ownership versus necessity } \\
\text { business ownership (3) }\end{array}$ \\
\hline $\begin{array}{l}\text { Pseudo } R^{2} \text { (Nagelkerke) } \\
\text { Observations }\end{array}$ & $\begin{array}{l}0.27 \\
8724\end{array}$ & $\begin{array}{c}0.27 \\
8724\end{array}$ & 8724 \\
\hline
\end{tabular}

Standard errors (clustered over country) in parentheses. Intercepts not shown. Country dummies are included and available from the authors upon request

$* * * p<0.01$

$* * p<0.05$

$* p<0.10$

two groups, and the remainder of this section is aimed at identifying these potentially different determinants of the two motivational types of business ownership.

In terms of the socioeconomic characteristics, opportunity and necessity business ownership seem to have roughly the same determinants. A notable exception is perceived household income, for which the coefficient is positive and significant for opportunity business ownership ( $p$ value $<0.01$ ) but not-significant for necessity business ownership $(p>0.10)$.

Regarding an individual's personality, there are generally no differences between columns 1 and 2 in terms of the sign and significance of the coefficients. For proactiveness, we observe a significant positive coefficient for opportunity business ownership ( $p<0.01)$ but not for necessity business ownership $(p>0.10)$. In terms of the perception variables, we observe significant negative coefficients $(p<0.10)$ for opportunity business ownership but non-significant coefficients for necessity business ownership $(p>0.10)$.

Column 3 of Table 3 takes necessity business ownership as the reference category. Hence, opportunity business ownership is directly compared to necessity business ownership. The results in this column allow a formal test of differences in determinants between opportunity and necessity business ownership (significance test of the coefficient in column 1 minus the coefficient in column 2). We find important differences between the two groups in terms of their socioeconomic characteristics, personality, and entrepreneurial perceptions. Various variables appear to have a stronger influence on opportunity business ownership than on necessity business ownership. Specifically, in terms of the socioeconomic factors, the probability of being an opportunity versus a necessity business owner is larger for male $(p<0.05)$ and younger $(p<0.01)$ business owners and for those who live in wealthier households $(p<0.01)$. The probability of being an opportunity versus a necessity business owner is significantly larger for those who prefer business ownership to paid employment $(p<0.01)$. Regarding personality, opportunity business owners are significantly more proactive $(p<0.10)$ and optimistic $(p<0.10)$. When the personality variables are added one by one rather than simultaneously, more differences emerge between opportunity and necessity 
business owners (see Sect. 4.3). Finally, opportunity business owners have significantly less negative perceptions about financial support during start-up $(p<0.10)$ than necessity business owners.

\subsection{Additional analyses}

\subsubsection{Multinomial probit}

We perform four additional analyses to test the robustness of our results. First, we perform another type of regression. Because of the independence of irrelevant alternatives assumption implicit in multinomial logit models and the problems with testing this assumption in these models (Cheng and Long 2007), we additionally perform a multinomial probit regression. Significant differences (cf. column 3 of Table 3) between opportunity and necessity business owners are again found for gender $(\beta=0.13 ; p<0.10)$, age $(\beta=-0.01 ; p<0.05)$, household income $(\beta=0.22 ; p<0.01)$, preference for self-employment versus wage-employment $(\beta=0.22 ; p<0.10)$, proactiveness $(\beta=0.12 ; p<0.05)$, optimism $(\beta=0.10$; $p<0.10)$, and perceived lack of financial support $(\beta=-0.11 ; p<0.05)$. An additional result is that opportunity business owners seem significantly less pessimistic than necessity business owners about the availability of start-up information $(\beta=-0.06 ; p<0.10)$.

\subsubsection{Mixed motivations}

Second, we incorporate another group of business owners in the analysis. We have indicated that individuals may be driven by a combination of pull and push motivations, and we are able to identify such individuals in the present dataset (231 business owners, approximately $12 \%$ of all business owners in the sample). Additional analyses reveal that this group of business owners with mixed motivations is more similar to opportunity business owners than to necessity business owners. In fact, Wald tests for the equivalence of coefficients across the three groups reveal that necessity business owners and those with mixed motivations are not inseparable. ${ }^{8}$ On the other hand, business owners with opportunity and mixed motivations are to a large extent similar. ${ }^{9}$

\subsubsection{Personality characteristics}

Third, a glance at the correlation coefficients between all pairs of variables reveals that the highest correlations are found among the personality characteristics [between 0.20 and 0.30 in most cases; see Table 4 (Appendix)]. Hence, it is likely

\footnotetext{
${ }^{8}$ The values of the test statistics are 109.12 ( $p$ value $<0.01$ ), 33.05 ( $p$ value $<0.01$ ), 26.83 ( $p$ value $<0.01$ ), and 8.12 ( $p$ value $<0.05$ ) for the full set of variables, excluding the country dummies, the socioeconomic variables, the personality variables, and the perception variables.

9 The values of the test statistics are 38.95 ( $p$ value $<0.01$ ), 5.78 ( $p$ value $>0.10), 8.40$ ( $p$ value $>0.10$ ), and 5.01 ( $p$ value $>0.10$ ) for the full set of variables, excluding the country dummies, the socioeconomic variables, the personality variables, and the perception variables.
} 
that some of the relationships between personality and opportunity versus necessity business ownership are captured, or mediated, by other personality aspects. As a robustness check, we include the personality aspects one by one rather than simultaneously in our model formulation. The coefficients of the following variables are significant for explaining the probability of being an opportunity versus a necessity business owner: risk-taking propensity $(\beta=0.15 ; p<0.01)$, general selfefficacy $(\beta=0.15 ; p<0.10)$, internal locus of control $(\beta=0.15 ; p<0.10)$, proactiveness $(\beta=0.23 ; p<0.01)$, autonomy $(\beta=0.13 ; p<0.05)$, innovativeness $(\beta=0.07 ; p>0.10)$, optimism $(\beta=0.18 ; p<0.01)$, and competitiveness $(\beta=0.12 ; p<0.10)$. Hence, we find a more important role of personality once the personality characteristics are included one by one in the analysis.

\subsubsection{Europe and Asia}

Fourth, differences across countries in terms of opportunity business ownership (Hechavarria and Reynolds 2009) suggest that cultural and economic factors may play a role in the relative importance of opportunity and necessity entrepreneurs. We analyze our European and Asian samples separately and arrive at the following results. For Europe (7279 observations), we find significant differences between opportunity and necessity business owners (cf. column 3 of Table 3 ) in terms of gender $(\beta=0.22 ; p<0.05)$, age $(\beta=-0.02 ; p<0.01)$, household income $(\beta=0.37 ; p<0.01)$, preference for self-employment $(\beta=0.41 ; p<0.01)$, proactiveness $(\beta=0.19 ; p<0.10)$, and optimism $(\beta=0.19 ; p<0.05)$. In addition, opportunity business owners are less pessimistic about the availability of sufficient start-up information $(\beta=-0.13 ; p<0.05)$ than necessity business owners. For the Asian sample (1038 observations), we find differences between the two groups of business owners for age $(\beta=-0.03 ; p<0.10)$, household income $(\beta=0.39 ; p<0.05)$, optimism $(\beta=0.26 ; p<0.01)$, and perceived lack of financial support $(\beta=-0.33 ; p<0.01)$. Opportunity business owners in our Asian sample are higher educated $(\beta=0.06 ; p<0.10)$ and more risk-taking $(\beta=0.35$; $p<0.01)$ than necessity business owners.

\section{Discussion and conclusion}

Using survey data for 29 European countries, three Asian countries, and the United States, we investigate the differences between opportunity and necessity business owners. We distinguish among socioeconomic characteristics, personality, and perceptions of the entrepreneurial environment. We use self-reports to classify respondents into being driven by opportunity or necessity motives. In this concluding section, we highlight how our findings add to the current literature on opportunity and necessity entrepreneurship. We also discuss interesting directions for future research.

Our univariate analysis reveals that the profiles of opportunity and necessity business owners differ markedly in terms of their socioeconomic characteristics, personality, and perceptions. In addition, our multivariate analysis concludes that 
the two types of business owners differ concerning some of the factors that inspire or hinder their engagement in entrepreneurship. Our findings therefore add to the large literature on the individual-level determinants of entrepreneurship. Recently, meta-analyses have revealed the influences of individual-level factors on the probability of being an entrepreneur (Simoes et al. 2015; Walter and Heinrichs 2015). The present study finds that some of these factors are more important for a specific subgroup of individuals, that is, business owners who engage in entrepreneurship because they see an opportunity rather than out of necessity. Specifically, we find differences for gender, age, income, personality (proactiveness and optimism), and perceptions of the entrepreneurial environment (in terms of financial support). Necessity entrepreneurship is likely to be related to an individual's dissatisfaction with his/her previous employment situation and is therefore different than the more voluntary character of opportunity entrepreneurship. ${ }^{10}$ This means that some well-known individual-level determinants of entrepreneurship are less likely to be related to necessity-based than to opportunity-based entrepreneurship.

The first empirical contribution of the present paper postulated in the introduction is its cross-national character and the ability to control for cross-country heterogeneity. We know that there exists large variety across countries regarding the distribution of necessity business ownership. For example, our Asian subsample is characterized by a very low percentage of business owners who are motivated by opportunity (35\%). This finding is in sharp contrast with the percentage of European business owners motivated by opportunity $(63 \%)$. In the case of China, for example, this difference can be explained by the relatively late emergence of entrepreneurship, the unfavorable institutional framework, and low scores for the 'doing business' indicators (Yang and Li 2008; Ahlstrom and Ding 2014). Although entrepreneurship had an important role in the post-war economic recovery of Japan (Hawkins 1993), entrepreneurship rates are low, and entrepreneurial support systems are underdeveloped (Welsh et al. 2014). For our Asian sample, we find that education and risk-taking increase the probability of being an opportunity versus a necessity business owner (Sect. 4.3). This may be related to the fact that risk-taking propensity is particularly important in China and developing economies in general to overcome the underdeveloped institutional environment (Tan 2001; see also Brünjes and Diez (2013) for such a finding in a Vietnamese sample). There have also been studies that refer to the high levels of education among entrepreneurs in transition economies (Estrin et al. 2006; Smallbone and Welter 2001).

The second contribution of the present study is the use of two groups of determinants of opportunity and necessity entrepreneurship that have not been investigated in earlier studies (in addition to the socioeconomic characteristics). The first group of determinants relates to the role of an individual's personality in determining his/her entrepreneurial motivation. We find evidence of a more important role of personality for engaging in opportunity business ownership -in

\footnotetext{
${ }^{10}$ Although our dataset does not contain a complete list of possible motivations, an additional analysis reveals that "an appropriate business idea" is very important for starting a new business among opportunity business owners, while "dissatisfaction with regard to your previous situation" is very important among necessity business owners.
} 
terms of proactiveness and optimism - than necessity business ownership. Perhaps surprisingly, risk attitudes do not play a differential role for opportunity and necessity business ownership. This result is in contrast with Block et al. (2015b), but similar risk attitudes among opportunity and necessity entrepreneurs have been found in some earlier studies as well (Amit and Muller 1995; Tyszka et al. 2011; Fossen and Büttner 2013). Here, is it important to note that we use a single, unidimensional measure of risk attitude and that an additional analysis reveals that the influence of this variable is captured by other personality characteristics. That is, in the absence of the other personality aspects in our model, opportunity business owners appear to be more risk-taking than necessity business owners. ${ }^{11}$ Future research could adopt a more extensive set of personality factors, including, for example, emotional stability, social boldness, dominance, and openness to change, to deepen the insight into personality differences between the two groups of entrepreneurs. It could also be relevant to study the implications of such personality differences, for example, for subsequent venture performance and survival for opportunity and necessity entrepreneurs. In terms of venture survival or exit from self-employment, it is worthwhile to distinguish between divergent exit paths (Rocha et al. 2015), such as involuntary and voluntary exits (Mueller and Stegmaier 2015; Van der Zwan and Hessels 2013). There is some evidence that necessity business owners are more likely to exit through failure (versus sell-off or transfer) than opportunity business owners (Van der Zwan and Hessels 2013).

The second group of determinants refers to one's perceptions of institutional arrangements for start-up activity. We find that individuals who believe that it difficult to start their own business due to a lack of available financial support are more likely to have necessity start-up motivations than opportunity motivations. Our multivariate analysis shows that this perception does not seem to discourage active involvement in entrepreneurial activity for necessity entrepreneurs but that it does for opportunity-motivated entrepreneurs. Future research may study whether other aspects of the entrepreneurial environment, such as the presence of public policy support for entrepreneurship, the legal infrastructure or the amount of technology transfer, are evaluated differently by opportunity and necessity business owners. ${ }^{12}$

Another way in which our study adds to the current research on entrepreneurship relates to the role of education. While we find an important role of education in our Asian subsample, we do not find that education influences the probability of being an opportunity versus a necessity business owner for our total sample (and European sample). The different impact of education depending on the sample under investigation corroborates the inconsistent evidence for this variable found in earlier studies on necessity entrepreneurship. Although there is some research that finds higher education levels among opportunity business owners than necessity business owners, we do not find such a role of educational attainment, operationalized in terms of the number of years of schooling an individual has had (Block and Wagner,

\footnotetext{
11 Note that a significant positive coefficient $(p<0.01)$ for risk attitudes is found in our main analysis restricted to Asian business owners (Sect. 4.3).

12 A preliminary analysis shows that opportunity business owners tend to perceive entrepreneurs more favorably than necessity business owners when asked for this in the present questionnaire.
} 
2010). This finding may have important implications. If necessity entrepreneurs have similar levels of human capital to opportunity entrepreneurs, there is perhaps less ground for concerns that they will end up as mediocre entrepreneurs. This observation is also inspired by the positive relationship between education and postentry performance that is found in some studies (Kolstad and Wiig 2015; Vivarelli 2013; Quatraro and Vivarelli 2015). Future research should investigate the human capital profiles of both groups of entrepreneurs. The result that opportunity and necessity business owners have similar levels of education raises the question of whether they differ in terms of more specific types of (entrepreneurship-related) human capital. There is evidence of the importance of such variables within the domain of opportunity and necessity entrepreneurship, making it a promising direction for future research. Studying firm performance, Baptista et al. (2014), for example, find that various forms of experience positively influence survival among opportunity entrepreneurs but not among necessity entrepreneurs.

Our study corroborates earlier findings on the importance of income or wealth for start-up motivation (Stephan et al. 2015). Perceived household income has a pronounced positive relationship with the probability of being an opportunity versus a necessity business owner. While earlier research has shown that the availability of financial resources increases one's probability to be engaged in business ownership in general (Simoes et al. 2015), we show that this holds true especially for opportunity-based business ownership. This finding could be related to the fact that some necessity business owners start their business to avoid or leave unemployment and, as a consequence, have fewer financial resources available than opportunity business owners. Higher income levels could also have implications for the performance of opportunity business owners, as investigated by, for example, Baptista et al. (2014), Block and Wagner (2010), Amit and Muller (1995), and Vivarelli $(2004,2013)$.

Research on latent entrepreneurship has revealed why people do not engage in entrepreneurship despite their revealed preference for an entrepreneurial career (Blanchflower et al. 2001; Grilo and Irigoyen 2006; Atasoy et al. 2013). We find that those who prefer having a business to being in paid employment are more likely to be opportunity than necessity business owners. This finding highlights the involuntary character of necessity business ownership in many cases. Furthermore, it corresponds with earlier research reporting lower satisfaction levels among necessity entrepreneurs than among opportunity entrepreneurs (Block and Wagner 2010) and research demonstrating the positive relationship between health and business ownership, which is found only for those who started a business out of opportunity (Rietveld et al. 2016). A promising research strand could be to investigate the health profiles of opportunity and necessity entrepreneurs in more detail, such as in terms of their physical and mental health characteristics.

From a policy perspective, given the observation that pull- and push-motivated entrepreneurs are different in terms of their profile and drivers, it can be argued that policies aimed at stimulating necessity-type entrepreneurs should not be similar to those stimulating opportunity-type entrepreneurs. For example, when policy measures promote preferences for self-employment, this will probably lead to an increase only in the amount of opportunity entrepreneurs and not in the amount of 
necessity entrepreneurs. We also find that the probability of being an opportunity business owner depends negatively on an individual's perception of financial startup support. From a policy point of view, this is important information as government policies could be targeted at modifying people's perceptions of the entrepreneurial infrastructure (Verheul et al. 2012; Van Stel and Stunnenberg 2006).

Our study has a number of limitations. For example, our findings may be subject to self-report biases. Individuals may not recognize their true characteristics and motivations (Amit and Muller 1995) or may rely on the subjective interpretation of the present situation to assess their motivation at the time of start-up. We do not take into account such dynamic aspects-a necessity-based start-up may evolve into an attractive alternative over time - although it has been demonstrated that motivations are relatively stable over the course of running a business (Stephan et al. 2015). Individuals may also report goals that are socially desirable, i.e., people may prefer to say they started a business because they want to exploit a profit opportunity rather than to admit they had no other option. Moreover, one could argue that the distinction between pull and push motivations (or between opportunity and necessity entrepreneurship) is relatively crude or incomplete. Giacomin et al. (2011) find that some individuals are driven neither by pull nor by push motivations. Therefore, there may be a third type of entrepreneurship: entrepreneurship as a hobby.

Open Access This article is distributed under the terms of the Creative Commons Attribution 4.0 International License (http://creativecommons.org/licenses/by/4.0/), which permits unrestricted use, distribution, and reproduction in any medium, provided you give appropriate credit to the original author(s) and the source, provide a link to the Creative Commons license, and indicate if changes were made.

\section{Appendix}

This Appendix contains a correlation matrix.

See Table 4. 


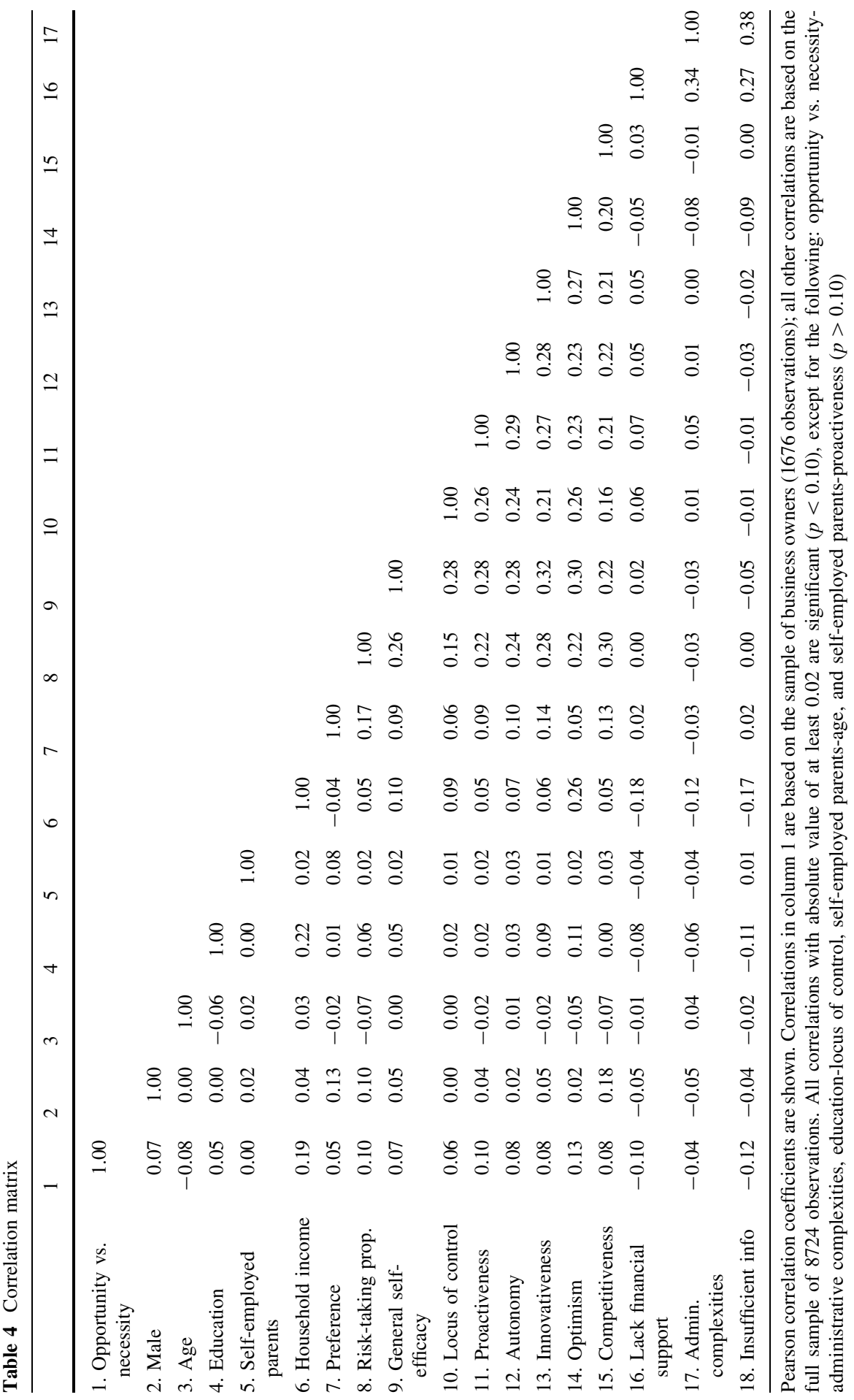




\section{References}

Acs, Z. J. (2006). How is entrepreneurship good for economic growth? Innovations Winter, 2006, 97-107.

Agarwal, R., \& Shah, S. K. (2014). Knowledge sources of entrepreneurship: firm formation by academic, user and employee innovators. Research Policy, 43, 1109-1133.

Ahlstrom, D., \& Ding, Z. (2014). Entrepreneurship in China: an overview. International Small Business Journal, 32(6), 610-618.

Ajzen, I. (1991). The theory of planned behavior. Organizational Behavior and Human Decision Processes, 50(2), 179-211.

Amit, R., \& Muller, E. (1995). "Push" and "pull” entrepreneurship. Journal of Small Business and Entrepreneurship, 12(4), 64-80.

Arenius, P., \& Minniti, M. (2005). Perceptual variables and nascent entrepreneurship. Small Business Economics, 24(3), 233-247.

Atasoy, H., van der Zwan P., Tiongson, E. \& Sanchez-Paramo C. (2013). Latent entrepreneurship in the East Central Asia region. World Bank Working Paper, April 1, 2013.

Audretsch, D. B., \& Vivarelli, M. (1996). Determinants of new firm start-ups in Italy. Empirica, 23, 91-105.

Baptista, R., Karaöz, M., \& Mendonça, J. (2014). The impact of human capital on the early success of necessity versus opportunity-based entrepreneurs. Small Business Economics, 42(4), 831-847.

Benz, M., \& Frey, B. S. (2008a). The value of doing what you like: evidence from the self-employed in 23 countries. Journal of Economic Behavior \& Organization, 68(3), 445-455.

Benz, M., \& Frey, B. S. (2008b). Being independent is a great thing: subjective evaluations of selfemployment and hierarchy. Economica, 75(298), 362-383.

Bergmann, H., \& Sternberg, R. (2007). The changing face of entrepreneurship in Germany. Small Business Economics, 28, 205-221.

Birley, S., \& Westhead, P. (1994). A taxonomy of business start-up reasons and their impact on firm growth and size. Journal of Business Venturing, 9, 7-31.

Blanchflower, D. G., Oswald, A., \& Stutzer, A. (2001). Latent entrepreneurship across nations. European Economic Review, 45(4), 680-691.

Block, J., \& Koellinger, P. (2009). I can't get no satisfaction-Necessity entrepreneurship and procedural utility. Kyklos, 62(2), 191-209.

Block, J. H., Kohn, K., Miller, D., \& Ullrich, K. (2015a). Necessity entrepreneurship and competitive strategy. Small Business Economics, 44(1), 37-54.

Block, J., \& Sandner, P. (2009). Necessity and opportunity entrepreneurs and their duration in selfemployment: evidence from German micro data. Journal of Industry, Competition and Trade, 9(2), 117-137.

Block, J., Sandner, P., \& Spiegel, F. (2015b). How do risk attitudes differ within the group of entrepreneurs? The role of motivation and procedural utility. Journal of Small Business Management, 53(1), 183-206.

Block, J. H., \& Wagner, M. (2010). Necessity and opportunity entrepreneurs in Germany: characteristics and earnings differentials. Schmalenbach Business Review, 62, 154-174.

Bönte, W., \& Piegeler, M. (2013). Gender gap in latent and nascent entrepreneurship: driven by competitiveness. Small Business Economics, 41(4), 961-987.

Bosma, N. (2013). The Global Entrepreneurship Monitor (GEM) and its impact on entrepreneurship research. Foundations and Trends in Entrepreneurship, 9(2), 143-248.

Brockhaus, R. H. (1980). The effect of job dissatisfaction on the decision to start a business. Journal of Small Business Management, 18, 37-43.

Brünjes, J., \& Diez, J. R. (2013). 'Recession push' and 'prosperity pull'entrepreneurship in a rural developing context. Entrepreneurship \& Regional Development, 25(3-4), 251-271.

Calderon, G., Iacovone, L., \& Juarez, L. (2016). Opportunity versus necessity: understanding the heterogeneity of female micro-entrepreneurs. The World Bank Economic Review, doi:10.1093/ wber/lhw010.

Caliendo, M., Fossen, F., \& Kritikos, A. S. (2014). Personality characteristics and the decisions to become and stay self-employed. Small Business Economics, 42(4), 787-814.

Carter, N. M., Gartner, W. B., Shaver, K. G., \& Gatewood, E. J. (2003). The career reasons of nascent entrepreneurs. Journal of Business Venturing, 18, 13-39. 
Cheng, S., \& Long, J. S. (2007). Testing for IIA in the multinomial logit model. Sociological Methods \& Research, 35(4), 583-600.

Cromie, S., \& Hayes, J. (1991). Business ownership as a means of overcoming job dissatisfaction. Personnel Review, 20, 19-24.

Darnihamedani, P., \& Hessels, J. (2016). Human capital as a driver of innovation among necessity-based entrepreneurs. International Review of Entrepreneurship, 14(1), 1-23.

De Jong, J. P., \& Marsili, O. (2015). The distribution of Schumpeterian and Kirznerian opportunities. Small Business Economics, 44(1), 19-35.

Estrin, S., Meyer, K., \& Bytchkova, M. (2006). Entrepreneurship in transition economies. In M. Casson (Ed.), The Oxford Handbook of Entrepreneurship (pp. 693-723). Oxford: Oxford University Press.

Fossen, F. M., \& Büttner, T. J. (2013). The returns to education for opportunity entrepreneurs, necessity entrepreneurs, and paid employees. Economics of Education Review, 37, 66-84.

Foti, A., \& Vivarelli, M. (1994). An econometric test of the self-employment model: the case of Italy. Small Business Economics, 6, 81-93.

Galbraith, C.S., \& Latham, D.R. (1996). Reluctant entrepreneurs: factors of participation, satisfaction, and success. In: Frontiers of Entrepreneurship Research 1996, Babson Park: Babson College.

García-Quevedo, J., Pellegrino, G., \& Vivarelli, M. (2014). R\&D drivers and age: are young firms different? Research Policy, 43(9), 1544-1556.

Giacomin, O., Janssen, F., Guyot, J. L., \& Lohest, O. (2011). Opportunity and/or necessity entrepreneurship? The impact of the socio-economic characteristics of entrepreneurs, MPRA Paper No. 29506, online at https://mpra.ub.uni-muenchen.de/29506.

Gilad, B., \& Levine, P. (1986). A behavioral model of entrepreneurial supply. Journal of Small Business Management, 4, 45-53.

Gkypali, A., Rafailidis, A., \& Tsekouras, K. (2015). Innovation and export performance: do young and mature innovative firms differ? Eurasian Business Review, 5(2), 397-415.

Grilo, I., \& Irigoyen, J. M. (2006). Entrepreneurship in the EU: to wish and not to be. Small Business Economics, 26(4), 305-318.

Grilo, I., \& Thurik, A. R. (2008). Determinants of entrepreneurial engagement levels in Europe and the US. Industrial and Corporate Change, 17, 1113-1145.

Hamilton, R. T., \& Harper, D. A. (1994). The entrepreneur in theory and practice. Journal of Economic Studies, 21(6), 3-18.

Hawkins, D. I. (1993). New business entrepreneurship in the Japanese economy. Journal of Business Venturing, 8(2), 137-150.

Hechavarria, D. M., \& Reynolds, P. D. (2009). Cultural norms \& business start-ups: the impact of national values on opportunity and necessity entrepreneurs. International Entrepreneurship and Management Journal, 5(4), 417-437.

Hessels, J., van Gelderen, M., \& Thurik, R. (2008). Entrepreneurial motivations, aspirations and their drivers. Small Business Economics, 31(3), 323-339.

Hisrich, R. D., \& Brush, C. (1986). Characteristics of the minority entrepreneur. Journal of Small Business Management, 24, 1-8.

Kautonen, T., \& Palmroos, J. (2010). The impact of a necessity-based start-up on subsequent entrepreneurial satisfaction. International Entrepreneurship and Management Journal, 6(3), 285-300.

Knight, F. (1921). Risk, Uncertainty, and Profit. Boston: Houghton Mifflin Company.

Koellinger, P. D., \& Minniti, M. (2006). Not for lack of trying: American entrepreneurship in black and white. Small Business Economics, 27, 59-79.

Koellinger, P. D., \& Thurik, A. R. (2012). Entrepreneurship and the business cycle. Review of Economics and Statistics, 94(4), 1143-1156.

Kolstad, I., \& Wiig, A. (2015). Education and entrepreneurial success. Small Business Economics, 44(4), 783-796.

Morales-Gualdrón, S. T., \& Roig, S. (2005). The new venture decision: an analysis based on the GEM project database. International Entrepreneurship and Management Journal, 1, 479-499.

Mueller, S., \& Stegmaier, J. (2015). Economic failure and the role of plant age and size. Small Business Economics, 44(3), 621-638.

Oxenfeldt, A. R. (1943). New Firms and Free Enterprise. Washington DC: American Council on Public Affairs.

Parker, S. C. (1996). A time-series model of self-employment under uncertainty. Economica, 63(251), 459-475. 
Parker, S. C. (1997). The effects of risk on self-employment. Small Business Economics, 9(6), 515-522.

Pellegrino, G., Piva, M., \& Vivarelli, M. (2012). Young firms and innovation: a microeconometric analysis. Structural Change and Economic Dynamics, 23(4), 329-340.

Quatraro, F., \& Vivarelli, M. (2015). Drivers of entrepreneurship and post-entry performance of newborn firms in developing Countries. The World Bank Research Observer, 30(2), 277-305.

Reynolds, P., Autio, E., De Bono, N., Servais, I., Lopez-Garcia, P., Chin, N., et al. (2005). Global enterprise monitor: data collection design and implementation 1998-2003. Small Business Economics, 24(3), 205-231.

Reynolds, P.D., Camp, S.M., Bygrave, W.D., Autio, E. and M. Hay (2001). Global Entrepreneurship Monitor, 2001 Executive Report.

Rietveld, C. A., Bailey, H., Hessels, J., \& van der Zwan, P. (2016). Health and entrepreneurship in four Caribbean Basin countries. Economics and Human Biology, 21, 84-89.

Ritsilä, J., \& Tervo, H. (2002). Effects of unemployment on new firm formation: micro-level panel data evidence from Finland. Small Business Economics, 19(1), 31-40.

Rocha, V., Carneiro, A., \& Varum, C. A. (2015). Entry and exit dynamics of nascent business owners. Small Business Economics, 45(1), 63-84.

Sarasvathy, S. D. (2004). Constructing corridors to economic primitives. Entrepreneurial opportunities as demand-side artifacts. In J. E. Butler (Ed.), Opportunity Identification and Entrepreneurial Behavior (pp. 291-312). Charlotte: Information Age Publishing Inc.

Scheinberg, S., \& MacMillan, I. C. (1988). An 11 country study of motivations to start a business. In B. A. Kirchoff, W. A. Long, W. E. McMullan, K. H. Vesper, \& W. E. Wetzel Jr. (Eds.), Frontiers of Entrepreneurship Research (pp. 669-687). Wellesley: Babson College.

Shane, S., Kolvereid, L., \& Westhead, P. (1991). An exploratory examination of the reasons leading to new firm formation across country and gender. Journal of Business Venturing, 6, 431-446.

Shapero, A., \& Sokol, L. (1982). The social dimensions of entrepreneurship. In C. Kent, D. Sexton, \& K. H. Vesper (Eds.), The Encyclopedia of Entrepreneurship (pp. 72-90). Englewood Cliffs: PrenticeHall.

Simoes, N., Crespo, N., \& Moreira, S. B. (2015). Individual determinants of self-employment entry: what do we really know? Journal of Economic Surveys,. doi:10.1111/joes.12111.

Smallbone, D., \& Welter, F. (2001). The distinctiveness of entrepreneurship in transition economies. Small Business Economics, 16(4), 249-262.

Stephan, U., Hart, M., Mickiewicz, T., \& Drews, C. C. (2015). Understanding motivations for entrepreneurship, BIS Research paper No. 212, online at http://eprints.aston.ac.uk/25296/1/ Understanding_motivations_for_entrepreneurship.pdf. Accessed 26 Oct 2016.

Storey, D. J., \& Jones, A. M. (1987). New firm formation-A labor market approach to industrial entry. Scottish Journal of Political Economy, 34, 37-51.

Tan, J. (2001). Innovation and risk-taking in a transitional economy: a comparative study of Chinese managers and entrepreneurs. Journal of Business Venturing, 16(4), 359-376.

Thurik, A. R. (2014). Entrepreneurship and the business cycle. IZA World of Labor, doi:10.15185/izawol. 90.

Thurik, A. R., Carree, M. A., Van Stel, A. J., \& Audretsch, D. B. (2008). Does self-employment reduce unemployment? Journal of Business Venturing, 23, 673-686.

Tyszka, T., Cieślik, J., Domurat, A., \& Macko, A. (2011). Motivation, self-efficacy, and risk attitudes among entrepreneurs during transition to a market economy. Journal of Socio-Economics, 40(2), 124-131.

Van der Zwan, P., and Hessels, J. (2013). Start-up motivation and (in)voluntary exit. Panteia Research Report, H201309, http://ondernemerschap.panteia.nl/pdf-ez/h201309.pdf. Accessed 12 August 2016.

Van der Zwan, P., Thurik, R., \& Grilo, I. (2010). The entrepreneurial ladder and its determinants. Applied Economics, 42(17), 2183-2191.

Van Stel, A., \& Stunnenberg, V. (2006). Linking business ownership and perceived administrative complexity. Journal of Small Business and Enterprise Development, 13(1), 7-22.

Verheul, I., Thurik, R., Grilo, I., \& Van der Zwan, P. (2012). Explaining preferences and actual involvement in self-employment: gender and the entrepreneurial personality. Journal of Economic Psychology, 33(2), 325-341.

Vivarelli, M. (2004). Are all the potential entrepreneurs so good? Small Business Economics, 23, 41-49.

Vivarelli, M. (2013). Is entrepreneurship necessarily good? Microeconomic evidence from developed and developing countries. Industrial and Corporate Change, 22(6), 1453-1495. 
Walter, S. G., \& Heinrichs, S. (2015). Who becomes an entrepreneur? A 30-years-review of individuallevel research. Journal of Small Business and Enterprise Development, 22(2), 225-248.

Welsh, D. H., Memili, E., Kaciak, E., \& Ochi, M. (2014). Japanese women entrepreneurs: implications for family firms. Journal of Small Business Management, 52(2), 286-305.

Wennekers, S., van Stel, A. J., Thurik, A. R., \& Reynolds, P. (2005). Nascent entrepreneurship and the level of economic development. Small Business Economics, 24, 293-309.

Wong, P. K., Ho, Y. P., \& Autio, E. (2005). Entrepreneurship, innovation and economic growth: evidence from GEM data. Small Business Economics, 24, 335-350.

Xavier-Oliveira, E., Laplume, A. O., \& Pathak, S. (2015). What motivates entrepreneurial entry under economic inequality? The role of human and financial capital. Human Relations, 68(7), 1183-1207.

Yang, J. Y., \& Li, J. (2008). The development of entrepreneurship in China. Asia Pacific Journal of Management, 25(2), 335-359. 